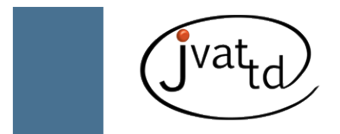

\title{
Triple bothropic envenomation in horses caused by a single snake
}

\author{
Chiacchio SB (1), Martins GTB (1), Amorim RM (1), Gonçalves RC (1), Barraviera B (2, 3), Ferreira
} Junior RS $(2,3)$

(1) Large Animal Service, School of Veterinary Medicine and Animal Husbandry, São Paulo State University (UNESP - Univ Estadual Paulista), Botucatu, São Paulo State, Brazil; (2) Center for the Study of Venoms and Venomous Animals, São Paulo State University (UNESP - Univ Estadual Paulista), Botucatu, São Paulo State, Brazil; (3) Department of Tropical Diseases, Botucatu Medical School, São Paulo State University (UNESP - Univ Estadual Paulista), Botucatu, São Paulo State, Brazil.

\begin{abstract}
In the present study, snakebites caused by a single Bothrops pauloensis simultaneously affecting three male adult horses are described. Whereas the first two affected horses were six years old, the third was 16 years old; they weighed respectively 555,550 and $500 \mathrm{~kg}$. All horses presented swollen muzzles. The first animal received an initial antivenom dose of 19 vials and adjuvant medication, it was also subjected to tracheostomy due to the progression of acute respiratory failure. The second and third horses respectively received 15 vials of antivenom each, in addition to adjuvant medication. Due to continuous changes in blood coagulation observed during hospitalization, the first and the second horses received five more vials of antivenom, respectively, in the second and third days of treatment. The first animal was discharged on $15^{\text {th }}$ day and the other on the $8^{\text {th }}$ day of hospitalization. Several factors including the main actions of Bothrops venom (coagulation, proteolytic and vasculotoxic activities), the importance of early diagnosis based on clinical history and clinical examination suggesting the diagnosis of Bothrops snakebite, the adequate doses of antivenom, and finally the immediate tracheostomy are herein discussed. The tracheostomy, required to save the life of the first horse, should only occur after the administration of antivenom and control measures for changes in blood coagulation.
\end{abstract}

Key words: Bothrops, snakebite, equine, antivenom, tracheostomy.

\section{INTRODUCTION}

In Brazil, 80 to $90 \%$ of the human envenomations provoked by snakes are caused by the Bothrops genus $(1,2)$. Regarding animal victims, due to their widespread distribution, aggressiveness and potent venom, Bothrops snakes are responsible for most fatal snakebites, which represent a great economic loss for animal breeders $(2,3)$.

Bothrops snake venoms have proteolytic or necrotizing, coagulant, vasculotoxic and nephrotoxic actions that provoke systemic changes and significant clinical signs at the bite site, including edema, pain, ecchymosis, and bleeding $(4,5)$. The coagulation abnormalities may be accompanied by hemorrhagic phenomena such as gingival bleeding, hematuria and bleeding of fresh wounds $(6,7)$. The venom contains a complex mixture of enzymes, peptides and proteins of low molecular weight that present specific chemical and biological activities. For instance: hyaluronidases promote rapid absorption and dispersion of the venom; hemotoxins and cytolysins provoke local inflammation, necrosis, vascular and epithelial damage; phospholipases A and esterases alter the membrane permeability releasing histamine and bradykinin $(8,9)$.

There is considerable variation in susceptibility of different animals to snake venoms. In the experiments conducted by Araujo and Belluomini (10), horses were more sensitive to snake venom than other domestic animals. 
Usually, horses are bitten on the muzzle due to their curiosity to investigate the snake. This is by far the most dangerous site for a bite, since the resulting swelling often closes both nostrils and causes suffocation, which can lead the animal to death within a few minutes. Deaths from Bothrops snakebites in horses are rare in Brazil, so this type of report, in addition to accurate diagnosis, is important to avoid economic losses when animals have high commercial value (11). Therefore, the aim of this study was to describe a case of snakebites in three adult horses caused by the same snake, as well as the symptoms and treatment.

\section{CASE REPORT}

Three adult horses were attended at the Medical Clinic for Large Animals of the Veterinary Hospital, School of Veterinary Medicine and Animal Husbandry, São Paulo State University, UNESP, Botucatu, São Paulo, Brazil. All had swelling on the muzzles and difficulty to drink water and feed. The case history was provided by homeowners who had found a snake in the paddock where the animals were housed.
The snake was captured alive and taken to the veterinary hospital. The owners were not able to inform how much time had elapsed since the snakebites.

The first horse was a male purebred English horse with six years old, weighting $555 \mathrm{~kg}$ and showing black and reddish brown coat; the second horse was also a six-year-old male, AngloArabian (Thoroughbred), weighting $500 \mathrm{~kg}$ with white coat (dapple), and the third horse was a 16-year-old Andaluz male, weighting $560 \mathrm{~kg}$ with chestnut coat. All horses had large swelling on the muzzle when they were admitted to the medical clinic.

The three animals were housed in a paddock with 33 other horses that showed no symptoms. They received animal feed $(4 \mathrm{~kg} / \mathrm{animal})$ twice a day, half bale of coastcross hay, minerals and water ad libitum. All horses had been wormed and vaccinated against rabies and encephalitis.

Additionally, the following diagnostic procedures were carried out: snake identification, clinical exam, CBC, quantification of biochemical parameters (urea and creatinine), evaluation of coagulation and urinary profiles, and analysis for hematozoa infection.

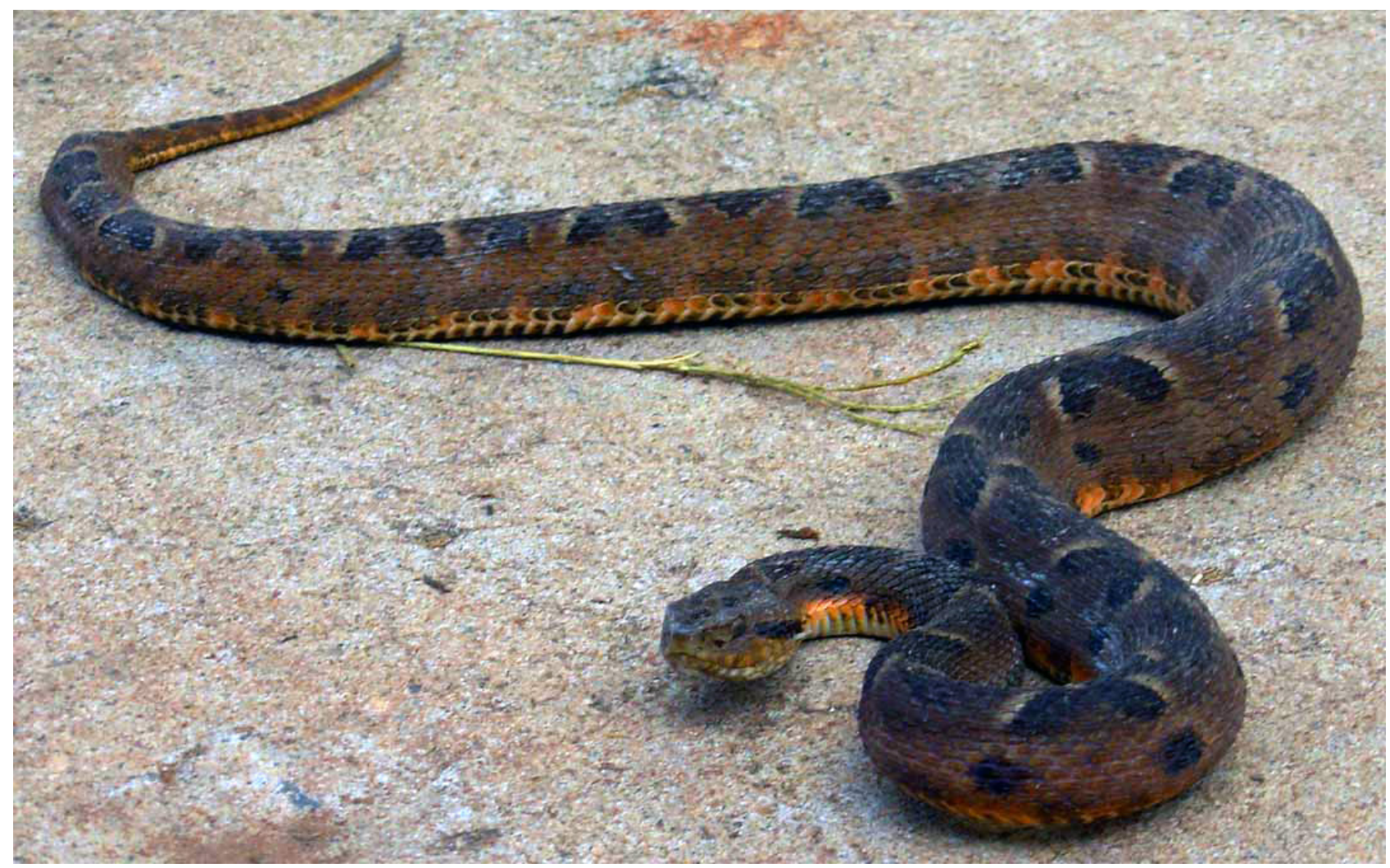

Figure 1. Bothrops pauloensis snake, popularly known as "jararaca pintada", responsible for the three snakebites. 
The snake was identified by the staff of the Center for Study of Venoms and Venomous Animals as an adult Bothrops pauloensis, recently renamed Bothropoides pauloensis, popularly known in Brazil as "jararaca pintada" (12) (Figure 1).

The clinical examination of the first animal showed body temperature of $38.2^{\circ} \mathrm{C}$, respiratory and heart rates respectively of 20 breaths per minute and 36 beats per minute (bpm), intense edema on the muzzle (Figure 2) and dyspnea due to edema. At initial evaluation, the horse presented incoagulable blood. Other tests revealed that urine $\mathrm{pH}$ was 6.0 , density was greater than 1040 , protein was $30 \mathrm{mg} / \mathrm{dL}$, glucose was $100 \mathrm{mg} / \mathrm{dL}$, and positive results of occult blood (high level). The clinical diagnosis was severe

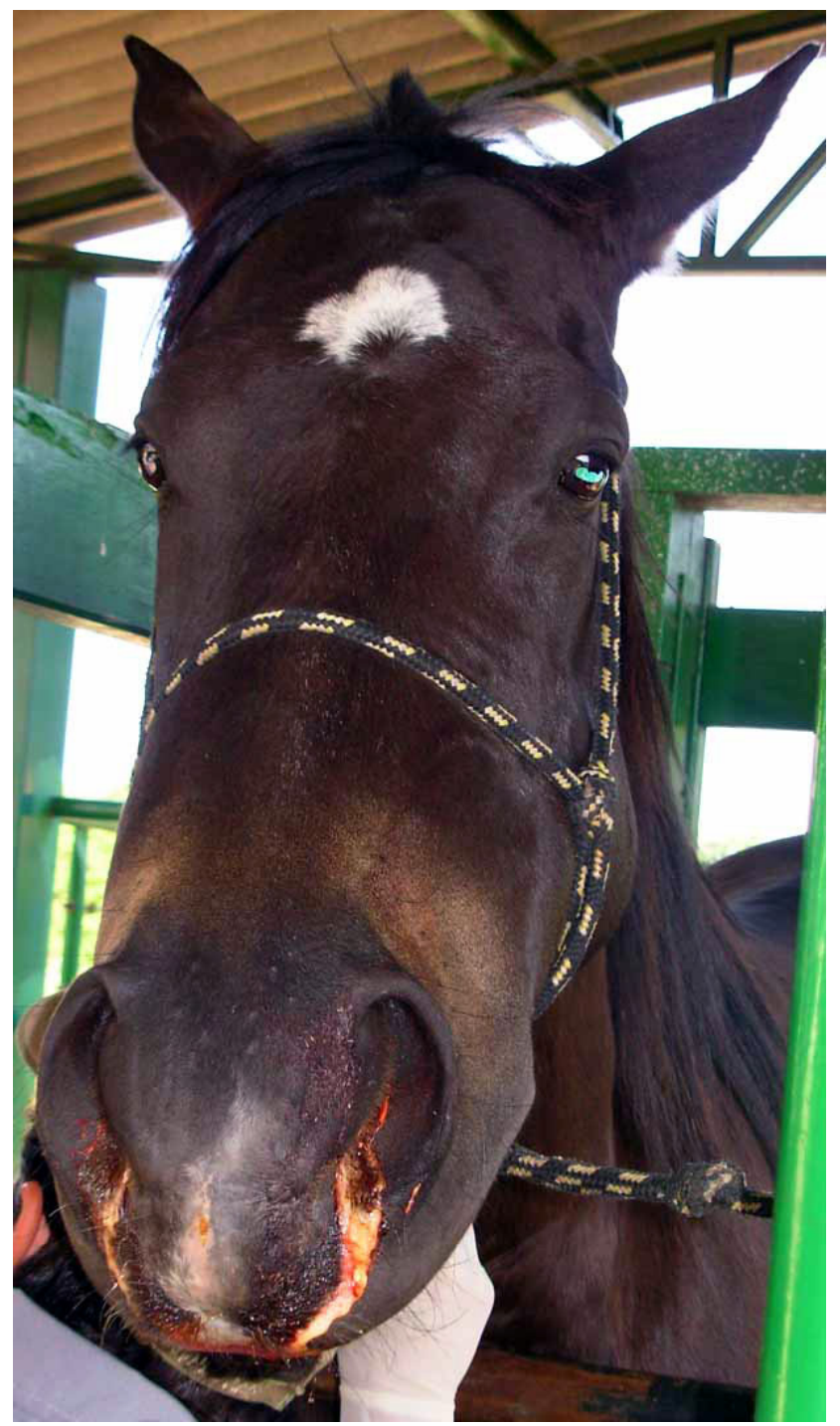

Figure 2. Severe edema on the muzzle of the first horse. bothropic envenomation. Treatment started with 19 vials of snake antivenom (anti-BothropsCrotalus Vencofarma ${ }^{\oplus}$, Brazil) intravenously (IV) administered, hydration with 15 L of Ringer's solution and Ringer's lactate solution, flunixin meglumine $(1.1 \mathrm{mg} / \mathrm{kg})$ intramuscularly (IM), furosemide $(1 \mathrm{mg} / \mathrm{kg} \mathrm{IV})$ and $150 \mathrm{~mL}$ of calcium chloride $10 \%$. This animal progressed to severe acute respiratory failure and was subjected to an emergency tracheostomy. Due to the great bleeding in the region of the tracheostomy wound, it also received six bags (3 L each) of whole blood (Figure 3).

The first horse remained at the veterinary hospital. On the second day, the edema had decreased, clotting time was 25 minutes, and hematocrit was $32 \%$. The treatment was maintained with IM flunixin meglumine (1.1 $\mathrm{mg} / \mathrm{kg}$ ) and IV hydration (5 L of Ringer's solution and $5 \mathrm{~L}$ of Ringer's lactate solution), plus five ampoules of snakebite antivenom due to changes in blood coagulation. On the third day, there was a greater reduction of edema, clotting time was 19 minutes and the drugs were limited to IM

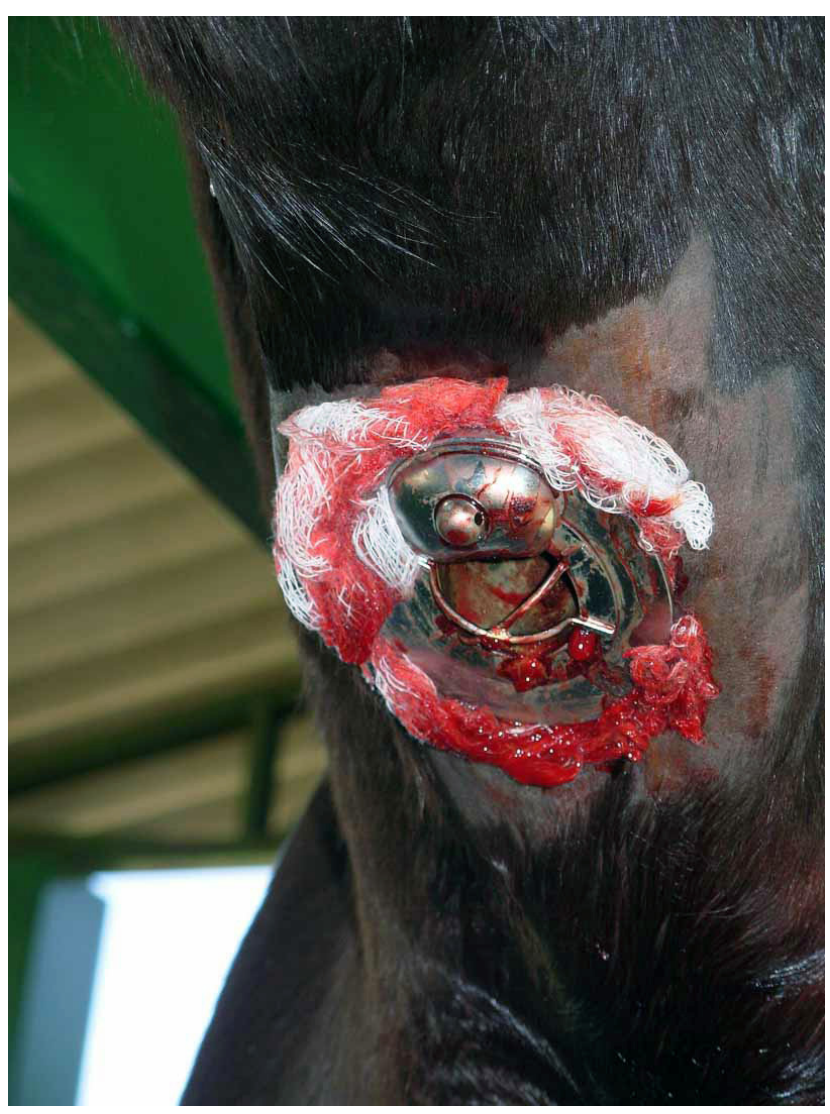

Figure 3. Emergency tracheostomy due to the presence of acute respiratory failure. 
flunixin meglumine $(1.1 \mathrm{mg} / \mathrm{kg})$. Later, on the fifth day, clotting time was 19 minutes, blood urea nitrogen was $40.6 \mathrm{mg} / \mathrm{dL}$ (reference range: 10 to $24 \mathrm{mg} / \mathrm{dL}$ ), creatinine level was $1.0 \mathrm{mg} / \mathrm{dL}$ (1.2 to $1.9 \mathrm{mg} / \mathrm{dL}$ ), red blood cell count was 5.450.000/ $\mu \mathrm{L}$, hemoglobin was $9.0 \mathrm{~g} / \mathrm{dL}$, hematocrit was $25 \%$, total protein level was $7.6 \mathrm{~g} / \mathrm{dL}$ (6 to $8 \mathrm{~g} /$ $\mathrm{dL}$ ), fibrinogen level was $600 \mathrm{mg} / \mathrm{dL}$ (1.2 to 4.9 $\mathrm{g} / \mathrm{L}$ ), leukocytes were $11.707 / \mu \mathrm{L}$ (5.2 to $13.9 \mathrm{x}$ $103 / \mu \mathrm{L})$, segmented neutrophils were $7.610 /$ $\mu \mathrm{L}$, lymphocytes were $1.756 / \mu \mathrm{L}$ and monocytes were $2.341 / \mu \mathrm{L}$. Furthermore, Babesia equi and Babesia caballi were detected. The animal remained hospitalized due to hemoparasitosis and treated with imidocarb dipropionate $(2 \mathrm{mg} /$ $\mathrm{kg})$. Afterward, the first horse was discharged on the $15^{\text {th }}$ day after admission.

The second horse had a body temperature of $38.2^{\circ} \mathrm{C}$, respiratory and heart rates of respectively 20 breaths per minute and $44 \mathrm{bpm}$, and moderate edema on the muzzle. At initial evaluation, the horse presented incoagulable blood. The clinical diagnosis was severe bothropic envenomation. Treatment was initiated with 15 vials of snake antivenom (anti-Bothrops-Crotalus Vencofarma ${ }^{\circ}$, Brazil) IV, hydration with $7 \mathrm{~L}$ of Ringer's solution and $8 \mathrm{~L}$ of Ringer's lactate solution, flunixin meglumine $(1.1 \mathrm{mg} / \mathrm{kg} \mathrm{IM})$, and furosemide (0.5 $\mathrm{mg} / \mathrm{kg}$ IV). On the second day of hospitalization, the edema had diminished, clotting time was 22 minutes and hematocrit was 39\%. The horse was treated with flunixin meglumine $(1.1 \mathrm{mg} / \mathrm{kg} \mathrm{IM})$ and hydration (5 L of Ringer's solution and $5 \mathrm{~L}$ of Ringer's lactate solution). On the third day, the edema was smaller and clotting time was 25 minutes. The animal still received flunixin meglumine $(1.1 \mathrm{mg} / \mathrm{kg} \mathrm{IM})$ and five a vials of snake antivenom. The horse remained under observation for three more days. On the seventh day, it showed normal clotting time, blood urea nitrogen was $36.0 \mathrm{mg} / \mathrm{dL}$ (10 to $24 \mathrm{mg} / \mathrm{dL}$ ) and creatinine was $0.7 \mathrm{mg} / \mathrm{dL}$ (1.2 to $1.9 \mathrm{mg} / \mathrm{dL}$ ), so it was discharged on the eighth day after admission

The third animal had body temperature of $38.2^{\circ} \mathrm{C}$, respiratory and heart rates respectively of 20 breaths per minute and $40 \mathrm{bpm}$, and mild swelling on the muzzle. It also presented incoagulable blood presented at the initial evaluation. The clinical diagnosis was moderate bothropic envenomation. At first, the third horse received 15 vials of snake antivenom (anti-Bothrops-Crotalus Vencofarma ${ }^{\bowtie}$ Brazil)
IV, hydration (7 L of Ringer's solution and $8 \mathrm{~L}$ of Ringer's lactate solution), flunixin meglumine (1.1 $\mathrm{mg} / \mathrm{kg} \mathrm{IM})$, and furosemide $(0.5 \mathrm{mg} / \mathrm{kg} \mathrm{IV})$. The animal remained at the veterinary hospital. On the second day, the edema had decreased, clotting time was 32 minutes and hematocrit was 35\%. Similarly, it was treated with flunixin meglumine $(1.1 \mathrm{mg} / \mathrm{kg} \mathrm{IM})$, and hydration (5 L of Ringer's solution and $5 \mathrm{~L}$ of Ringer's lactate solution). On the third day, the edema had noticeably dimished, clotting time was 17 minutes, and the animal was receiving only flunixin meglumine $(1.1 \mathrm{mg} / \mathrm{kg}$ IM). The horse remained under observation for three days. On the seventh day, it showed normal clotting time, blood urea nitrogen was $40.6 \mathrm{mg} /$ $\mathrm{dL}(10$ to $24 \mathrm{mg} / \mathrm{dL})$ and creatinine was $1.0 \mathrm{mg} /$ $\mathrm{dL}(1.2$ to $1.9 \mathrm{mg} / \mathrm{dL})$; so, it was discharged on eighth day after admission.

\section{DISCUSSION}

Bothrops venom provokes rapid edema formation and necrosis, which for a long time were attributed to their proteolytic activity (13). However, it is not known yet whether these local venom effects can be reproduced by purified components, such as hemorrhagic principles or proteases, nor whether the proteolytic activity of the components occur concomitant with their tissue damaging action (14). Local effects include edema formation, hemorrhage, skin necrosis, and myonecrosis. Systemic effects may comprise pro- and anticoagulant activities, hemolysis, thrombocytopenia, and hypo- or (infrequently) hypertensive effects (15). The extent of systemic effects depends on the concentration of toxins injected, the bite site, and the rate at which these toxins are released into the circulation (16).

Some of the factors reported to influence the amount of toxin injected include the snake species, its age, the time since its last meal, and seasonal influences related to changes in feeding patterns or physiological responses (16). In addition, not all snakebites result in envenomations, for example, between 20 and $25 \%$ of pit viper bites are innocuous $(16,17)$. Therefore, the severity of clinical signs may vary considerably among snakebite victims.

In the present report, an adult Bothrops pauloensissnake, which measuresabout 60 to $90 \mathrm{~cm}$ in length, was able to cause serious envenomation in three adult horses with average weight of 540 
$\mathrm{kg}$ (18). The severe symptoms observed were caused mainly by the swelling on the muzzle and disturbances in blood coagulation. These animals would probably die if the appropriate veterinary care was not immediately provided.

Raposo et al. (19) described a Bothrops attack on a foal of one month old that was bitten on the left ear and developed pronounced edema, which spread to the chest and limbs. The animal died, and during necropsy petechiae and suffusions on the serosa, intestines, stomach, liver, spleen, lung and genitourinary system, as well as cerebral edema were found. Histological analysis revealed congestion and hemorrhage in various organs, muscle necrosis and acute renal tubular necrosis. These findings show and emphasize the potential of a bite caused by Bothrops snakes.

The most consistent clinical signs associated with snakebites in horses are acute swelling and edema at the bite site, which are also observed in cattle (9). In horses, snakebites frequently occur on their face, and subsequent swelling of the muzzle and external nostrils may result in partial or complete occlusion of nasal passages, remembering that this species can only breathe through their nose (20). Insertion of a rigid tube (endotracheal tube, large-bore syringe opened on both ends etc.) into the nasal passage may prevent complete occlusion. Though, a tracheostomy may be required in horses with severe pharyngeal or laryngeal swelling. An emergency tracheotomy tube may be made from a cuffed endotracheal tube shortened to reduce deadspace (21). Therefore, the tracheostomy performed in one of the horses was necessary to save its life.

The first animal received a high dose of specific snake antivenom (19 vials) on the first day, requiring a new application (five vials) on the second day due to changes in clotting time. After five days, the abnormal clotting time (19 minutes) indicated a suspicion of blood-borne parasitic infection. Subsequently, B. equi and B. caballi were found and appropriately treated. The parasitic disease contributed to worsen the bleeding and this condition should alert to snakebites.

The second horse received initially 15 vials of snake antivenom due to coagulation abnormalities and severity of symptoms. On the third day after admission, the coagulation time was 25 minutes, which certainly indicated the presence of remaining venom in its circulation and was properly treated with other five vials of antivenom for complete resolution of symptoms.

The third animal, even with a moderate swelling on the muzzle when compared to the other two animals, presented incoagulable blood and, therefore, received 15 vials of snake antivenom. On the third day, with a clotting time of 17 minutes, only supportive treatment was maintained, with complete clinical resolution on the seventh day.

In addition to specific treatment with antivenom a few hours after the snakebites, which prevented the evolution of symptoms, intense fluid therapy was also necessary. It ensures adequate hydration, improves renal perfusion, and provides cardiovascular support. Some animals may develop profound anemia attributable to coagulopathy, and hemorrhagic diathesis so that whole-blood transfusion may become necessary (PCV of $12 \%$ or less over a period of 24 to 48 hours) (22).

There is a surprisingly lack of information on the effectiveness of antivenom therapy in horses. In humans, however, parenteral administration of horse- or sheep-derived antivenoms constitutes the only scientifically validated treatment for moderate to severe snakebite envenomation (23, 24). In Brazil, there are specific and polyvalent antivenoms that neutralize both bothropic and crotalic venoms. But for veterinary use, the most accessible is the polyvalent one, a product that lacks purity and composed of IgG. The use of Fabbased products in veterinary medicine is limited due to their high costs $(2,25)$.

Historically, antivenom used to be administered via intramuscular or subcutaneous routes. In some cases, it was also injected directly into the bite site. Nowadays, all antivenoms must be intravenously injected, since via this route the results are more rapid, effective, and predictable (24). The goal of antivenom is to neutralize as much venom as possible in the shortest time, thus avoiding local effects. For animals, antivenom doses may vary substantially, ranging from 10 to $50 \mathrm{~mL}$ (one to five vials), depending on the severity of symptoms, time elapsed since the bite, sizes of the snake and of the affected animal.

According to some authors, non-steroidal anti-inflammatory drugs (NSAID) and cyclooxygenase inhibitors (such as flunixin meglumine, employed in the present case) are indicated for the treatment of accidents involving Bothrops snakes in cattle $(11,26,27)$. 
Association with diuretic drugs is necessary for rapid reduction of edema, which may lead to death depending on the affected body part. However, anti-inflammatory drugs act only on edema, presenting no action on the coagulant effect of Bothrops venom, which is neutralized only by specific antivenom.

Therefore, rapid veterinary care, use of specific antivenom in adequate dosage, and surgical intervention in one of the animals, along with supportive treatment with NSAID, diuretics and aggressive fluid therapy were essential for the favorable resolution of the three snakebites.

\section{COPYRIGHT}

(c) CEVAP 2011

\section{SUBMISSION STATUS}

Received: September 2, 2010.

Accepted: December 20, 2010.

Abstract published online: January 25, 2011.

Full paper published online: February 28, 2011.

\section{CONFLICTS OF INTEREST}

There is no conflict.

\section{CORRESPONDENCE TO}

RUI SEABRA FERREIRA JÚNIOR, Centro de Estudos de Venenos e Animais Peçonhentos, UNESP, Caixa Postal 577, Botucatu, 18618000, SP, Brasil. Phone: +55 143814 5446. Email: rseabra@cevap.org.br.

\section{REFERENCES}

1. Franco RL, Rocha CC, Jorge MT, Ribeiro LA. Snakebites in southern Minas Gerais state, Brazil. J Venom Anim Toxins. 2001;7(1):56-68.

2. Ferreira Jr RS, Barraviera B. Management of venomous snakebites in dogs and cats in Brazil. J Venom Anim Toxins incl Trop Dis. 2004;10(2):112-32.

3. Graça FAS, Peixoto PV, Coelho CD, Caldas SA, Tokarnia CH. Aspectos clínico-patológicos e laboratoriais do envenenamento crotálico experimental em bovinos. Pesq Vet Bras. 2008;28(6):261-70.

4. Ferreira Jr RS, Barraviera B. Tissue necrosis after canine bothropic envenoming: a case report. J Venom Anim Toxins. 2001;7(2):302-12.

5. Otero R, Gutiérrez J, Beatriz Mesa M, Duque E, Rodríguez O, Luis Arango J, et al. Complications of Bothrops, Porthidium, and Bothriechis snakebites in Colombia. A clinical and epidemiological study of 39 cases attended in a university hospital. Toxicon. 2002;40(8):1107-14.

6. Sano-Martins IS, Santoro ML, Castro SC, Fan HW, Cardoso JL, Theakston RD. Platelet aggregation in patients bitten by the Brazilian snake Bothrops jararaca. Thromb Res. 1997;87(2):183-95.

7. Gutiérrez JM, Rucavado A, Escalante T, Díaz C. Hemorrhage induced by snake venom metalloproteinases: biochemical and biophysical mechanisms involved in microvessel damage. Toxicon. 2005;45(8):997-1011.

8. Mendez MC, Riet-Correa F. Snakebite in sheep. Vet Hum Toxicol. 1995;37(1):62-3.

9. Caldas SA, Tokarnia CH, França TN, Brito MF, Graça FAS, Coelho CD, et al. Aspectos clínicopatológicos e laboratoriais do envenenamento experimental por Bothrops alternatus em bovinos. Pesq Vet Bras. 2008;28(6):303-1210.

10. Araujo P, Belluomini HE. Toxicidade de venenos ofídicos. Sensibilidade específica de animais domésticos e de laboratório. Mem Inst Butantan. 1960-2;30(1):143-56.

11. Tokarnia $\mathrm{CH}$, Peixoto PV. A importância dos acidentes ofídicos como causa de mortes em bovinos no Brasil. Pesq Vet Bras. 2006;26(2):5568.

12. Fenwick AM, Gutberlet Jr RL, Evans JA, Parkinson CL. Morphological and molecular evidence for phylogeny and classification of South American pit vipers, genera Bothrops, Bothriopsis, and Bothrocophias (Serpentes: Viperidae). Zool J Linnean Soc. 2009;156(1):617-40.

13. Queiroz LS, Petta CA. Histopathological changes caused by venom of urutu snake (Bothrops alternatus) in mouse skeletal muscle. Rev Inst Med Trop São Paulo. 1984;26(5):247-53.

14. Gutiérrez JM, Lomonte B. Phospholipase $A_{2}$ myotoxin from Bothrops snake venoms. Toxicon. 1995;33(11):1405-24.

15. White J. Overview of venomous snakes of the world. In: Dart R, editor. Medical toxicology. Philadelphia: Lippincott, Williams and Wilkins; 2004. p. 1543-59.

16. Landolt GA. Management of equine poisoning and envenomation. Vet Clin North Am Equine Pract. 2007;23(1):31-47.

17. Gold BS, Wingert WA. Snake venom poisoning in the United States: a review of therapeutic practice. South Med J. 1994;87(6):579-89.

18. Sawaya RJ, Marques OAV, Martins M. Composição e história natural das serpentes de Cerrado de Itirapina, São Paulo, sudeste do Brasil. Biota Neotrop. 2008;8(2):127-49.

19. Raposo JB, Méndez MC, Baialardi CEG, Raffi MB. Acidente ofídico em equino no 
sul do Brasil - Relato de caso. Rev da FZVA. 2000/2001;7/8(1):51-7.

20. Dickinson CE, Traub-Dargatz JL, Dargatz DA, Bennett DG, Knight AP. Rattlesnake venom poisoning in horses: 32 cases (1973-1993). J Am Vet Med Assoc. 1996;208(11):1866-71.

21. Schmitz DG. Toxicologic problems. In: Reed SM, Bayly WM, editors. Equine internal medicine. Philadelphia: W.B. Saunders; 1998. p. 981-1042.

22. Moss DD. Diseases associated with blood loss or hemostatic dysfunction. In: Smith BP, editor. Large animal internal medicine. St. Louis: Mosby; 1990. p. 1198-213.

23. Gutiérrez JM, Theakston RDG, Warrell DA. Confronting the neglected problem of snake bite envenoming: the need for a global partnership. PLoS Med. 2006;3(6):150-9.

24. World Health Organization. Rabies and envenomings. A neglected Public Health Issue.
Report of a Consultative Meeting. Geneva: WHO; 2007. $32 \mathrm{p}$

25. Rucavado A, Lomonte B. Neutralization of myonecrosis, hemorrhage, and edema induced by Bothrops asper snake venom by homologous and heterologous pre-existing antibodies in mice. Toxicon. 1996;34(5):567-77.

26. Novaes AP, Lucas S, Abe AS, Fernandes W, Puorto G, Almeida IL. Envenenamento botrópico em bovinos: tratamento opcional. Vet News. 1997;30(1):9-12.

27. Lago LA, Ferreira PM, Facury Filho EJ, Melo MM, Alzamora Filho F. Quadro clínico do envenenamento crotálico experimental em bovinos (Crotalus durissus terrificus crotamina positivo). Braz J Vet Res Anim Sci. 2000;37(4):312-5. 